\title{
Should Your IB Research Deal with
} Power?

\author{
John Child, University of Birmingham, UK
}

There has been a long-standing interest in the political behavior of multinational enterprises (MNEs). Yet international business (IB) research still has to come to grips with the key dynamic of such behavior-namely, the exercise of power. So, yes, in many cases you should deal with power in your IB research, but this is easier said than done. Here are some suggestions on a way forward and a question for you to answer. ${ }^{1}$

\section{The MNE Is a Political Actor}

Stewart Clegg (2017) recently claimed that "the central business of MNEs is politics by other means." This phenomenon has long been recognized in the theorization of the MNE and of its relations with governments (Boddewyn, 1988, 2016) as well as in the emerging perspectives of corporate political activity, political CSR, and non-market strategy. Nevertheless, despite considerable progress in framing the political relations between international firms and external institutions, the $d y$ namic processes through which MNEs take political initiatives remain obscure. These processes have essentially to do with the exercise of power, because, as Jeff Pfeffer put it (1981: 7): "politics is the study of power in action." Therefore, we need to take account of power and to think about how to do so. ${ }^{2}$

\section{We Have Been Skirting Around Polit- ical Issues}

The majority of studies on MNE-institution relations have conducted variance analyses employing databases and, less often, surveys as empirical sources. However, by eschewing a process model, ${ }^{3}$ researchers have distanced themselves from direct insights into the interactions between MNEs and institutional agencies - that is, into the how and why of what happens-so that political processes are implied but actually not investigated. Many articles in JIBS and other leading journals exhibit this limitation. To take two recent examples, both Edwards et al.
(2016) and Rathert (2016) raise the question of how national institutions affect MNE practices, and they develop full and enlightening theoretical rationales for addressing it. However, they are constrained by the inability of the data employed to throw light on the processes central to their theoretical rationales.

In a nutshell, most IB research has not been able to explain how governmental and other institutions matter for MNEs and what firms do about it so that the mechanisms behind many observed effects of institutions on MNE behavior remain ill-known (Van Hoorn \& Maseland 2016: 379). A major problem lies in the fact that key constructs such as power and influence are normally assessed through indirect measures.

Two instances of such indirect approaches are: (1) assessing MNE power to resist institutional constraints by measuring the extent of the standardization of MNE international practices among host countries as an indication of the MNE's ability to avoid national adaptations (Edwards et al., 2016) and (2) measuring host country institutional pressures on inward-investing enterprises by reference to the strength of the host country's rule of law and its technological endowment which governments will seek to protect from MNE acquisition (Meyer, Ding, Li, \& Zhang, 2014). Both examples rely on proxies for power. In the first one, limited institutional power is imputed to the high standardization of MNE practices which, however, might actually be welcomed in some host countries as "international best practice." In the second case, it is assumed that host country conditions are necessarily converted into effective pressures on MNEs.

\section{Addressing the Challenges}

Fortunately, a few studies have examined the politics of MNE institutional relations at closer range, and they point to a way forward. They generally focus on MNE initiatives and reactions vis-à-vis the constraints, threats, or opportunities present- 
ed by host country institutions, and they address the actions taken by MNEs to enhance their legitimacy, thereby providing insights into the rationales of key market actors and how they relate to their institutional counterparts. Given these objectives, the researchers normally employ a case study methodology and access participants directly in order to achieve a rich understanding that can contribute both to theory building and managerial recommendations. When combined with a longitudinal perspective, this approach enables researchers both to capture events and processes over time and to bridge levels of analysis by offering insights into the initiatives taken by corporate actors at the "micro-foundational" level to manage their institutional contexts. ${ }^{4}$

A pioneering study of this kind is that by Gifford and Kestler (2008), who investigated how a multinational mining company achieved local legitimacy and support for its activities by contributing to sustainable development in the Peruvian communities where it operated. Their study demonstrated the development of a legitimation strategy suited to the conditions of an emerging economy.

A more recent example is Darendeli and Hill's (2016) comparative case study of Turkish construction MNEs operating in Libya in a period of radically changing political conditions. They show that the success or failure of these firms in maintaining a viable presence was partly due to their choice of social and political ties to local power holders-namely, bureaucrats and local families. This is an IB study that offers direct insights into the political processes between MNEs and external parties in conditions of political threat.

Such studies come closer to analyzing the role of power and the exercise of influence as core dynamics in political relations between MNEs and external agents, but they are still uncommon, and this kind of research faces significant challenges. One is how to theorize the use of power as a process - in other words, the circumstances and events through which the potential to exercise power is translated into action. Another challenge is how to gain adequate empirical access to study it at sufficiently close hand. Nevertheless, as I will now illustrate, advances in the study of power by organizational scholars and political scientists offer helpful perspectives, while empirical access is not necessarily impossible.

\section{Getting to Grips with Power}

In the approach that colleagues and I adopted to incorporate power into IB research, we sought to account for the evolving relations over a 15 -year period between a large MNE port operator in China and institutional agents at local and central levels (Child, Tse, \& Rodrigues, 2013). Since these relations embodied various tensions and conflicts, we drew upon available concepts to develop a framework and methodology for
(1) identifying the power resources (or levers) available to both firms and their institutional counterparts and (2) revealing how the key actors sought to realize the potential of such levers to influence events and outcomes. The fundamental building blocks of our processual model were as follows:

1. Power resources. These resources are available to the firm and external agents, as adapted from French and Raven (1960), in terms of: (1) possessing material resources which provide the ability to reward; (2) the ability to coerce through force, intimidation, and the withholding of material resources such as investment; (3) legitimacy whereby the exercise of power is regarded as rightful by other parties; (4) reference (closely related to "charisma") whereby others are willing to accord power to persons or organizations that have gained their loyalty, identification, admiration, and the like, and (5) expertise whereby the competence held by, or attributed to, a person or organization creates a willingness to accept their authority. Relevant actors may possess several of these power resources which can be mutually reinforcing. In particular, material resources such as FDI can enhance other bases of MNE power such as coercion and legitimacy.

2. Relational capabilities. There is a necessary distinction between power resources and their effective use in influencing the events that drive the evolution of relations between MNEs and external organizations. Concepts such as "relational capabilities" and "relationship management" draw attention to this ability of MNEs and external agents to capitalize on their baseline sources of power within their evolving relationships. The processes of mobilizing support and engaging in legitimizing discourses belong here. Senior managers in the MNE we studied were very conscious of the importance not only of establishing personal relations with key government officials at local and national levels but also of creating a discourse that steered these relations toward a shared awareness of the win-win possibilities offered by the port's development. For example, by consistently emphasizing the messages of "establishing a world-class port" and "maximizing throughput growth" these managers were able to create a common platform with the government's developmental aspirations for China. This platform in turn facilitated the overcoming of opposition by agencies such as the port-based Customs Authority to the introduction of more efficient working practices.

3. Relational frameworks. Relationships between firms and governments-or more precisely between their key actors-construct an arena in which each party endeavors to influence the other. Here, the MNE may have some power to limit government enforcement and, vice versa, the firm's power can be restricted by the ability of governments to affect its opportunities and sources of competitive advantage (Barron, Pereda, \& Stacey, 2017). In the case we studied, the MNE enjoyed influence through, among other factors, its command of investment financing and advanced technology while government agencies

\section{AIB INSIGHTS}


possessed influence through factors such as their sovereign rights to grant or withhold official approvals. Outcomes are also partly dependent on each party's ability to mobilize support for their respective objectives, to define new possibilities and to achieve compatible sense-making among the participants. For example, the MNE mobilized the support of the port's city government when dealing with central authorities by offering tangible local development benefits to the former.

A political-action analysis employing these concepts rests on four fundamental assumptions which, I suggest, should underpin a political perspective in international business. The first is that we need to take account of a range of power resources, the importance of which, relative to each other, may change over time. The second assumption is that power operates through relationships and "is inseparable from interaction" (Clegg, Courpasson, \& Phillips, 2006: 6). The third one is that power is a "capacity" rather than the exercise of that capacity (Lukes, 2005). In other words, holding a power resource provides the potential for achieving influence but the outcome will depend on the dynamics of the relations with the other parties involved. The fourth assumption is that the translation of power into influence is facilitated through activities such as articulating mutually acceptable aspirations, formulating beneficial solutions, and cultivating personal trust within the relational framework existing between a firm's actors and relevant external parties.

\section{Tools for Analyzing Power}

The relations between MNEs and external bodies can evolve in cycles over time, which may be analyzed by applying three principal lenses to interpret the use of power. The first one considers the power resources that actors possess and which create initial conditions for the involved organizations to potentially exercise influence on one another regarding a given issue. The second lens examines how corporate leaders and external actors construct and use a relational framework with the intention of actually achieving influence. A key phenomenon here is the discourse that enables the parties to move to a sense of shared purpose. For example in the port case, a consistent discourse on the part of the MNE in terms of developing a world-class port for China projected a shared purpose between the firm and government, which led in less than three years from its opening to the port being officially designated as the pilot site for China's national port-development program. This designation, in turn, legitimated the new operating practices that the MNE sought to introduce. The third lens considers how the actual realization of influence translates into the policies and practices of the parties over time as well as feeding back into their respective power resources.

\section{The Critical Factor of Access}

Needless to say, this kind of research requires a high level of access by academics to key actors in a firm and in its political environment, and for this to be maintained over a lengthy period of time. Although close collaboration between researchers and the "subjects" of study always runs the risk of compromising objectivity, the depth and quality of information and the insight that it offers makes for a major qualitative advance over the general run of studies that have relied on impersonal data and proxy indicators.

In fact, objectivity can be enhanced through good access that opens up multiple data sources and so permits triangulation between, say, interviews and documentary data as well as between multiple strands of fieldwork. For example, there were several factors that opened up and maintained a high quality of access for conducting the port study_among them a long-standing personal link to the CEO through his involvement in previous survey research, the conduct of 21 Master's thesis studies in the port that were supervised by the principal researcher, and repeated on-site visits and interviews with company and institutional personnel.

Another longitudinal study of political interaction in Indonesia between a large company and external parties also illustrates how rich insights can be derived from access to a range of sources-interviews, company reports and media material (Dieleman \& Sachs, 2008) —although patience and persistence are required. The authors note that introductions were vital and that some interviews were only possible because of serendipity or through following a chain of connections.

Before you throw up your hands and say that this is all asking too much, it is worth recalling that power is present everywhere and we can study it in our own department, school, college or university. "This is not IB research," you may reply, but what about studying the units designed to attract, assist and direct foreign students, and to liaise with foreign higher education institutions? If not at your school, you can visit another one that does. Besides, there are countless trade and industry associations-local, regional or national - which often deal with IB issues. Even more active are the national and foreign governmental units attached to Departments of Commerce and/ or foreign embassies/consulates to promote foreign trade and investment. Start by inviting their executives to your classes, preceded or followed by a meeting or meal together so as to establish preliminary good rapport and gain access to power!

\section{Questions for You}

At the outset, I asked whether your research should deal with power. I believe IB research needs to take power into account because a political perspective founded on the analysis of power contributes to unpacking the dynamics of relations between MNEs and the government actors with whom they deal in their environments. Yet, even if the relevance of power is acknowledged, why is it so neglected? If you have avoided power and a political perspective in your research, why is that? Is it because of conceptual and methodological problems? Or is it due to the 
difficulty of securing good access? What other problems have you encountered and what ways have you found of overcoming or mitigating them? Tell us of your positive and negative experiences, because we still have a lot to learn on this subject. Please send me your answers, questions, and comments through the AIB Insights interactive comments system, which you can access at https://aib.msu.edu/publications/insights. I will address them in a later issue of this journal.

\section{References}

Barron, A., Pereda, A., \& Stacey, S. 2017. Exploring the performance of government affairs subsidiaries: A study of organisation design and the social capital of European government affairs managers at Toyota Motor Europe and Hyundai Motor Company in Brussels. Journal of World Business, 52(2): 184-196.

Boddewyn, J. J. 1988. Political aspects of MNE theory. Journal of International Business Studies, 18(3): 341-363.

Boddewyn, J. J. 2016. International business-government relations research 1945-2015: Concepts, typologies, theories and methodologies. Journal of World Business, 51(1): 10-22.

Child, J., Tse, K. K.-T., \& Rodrigues, S. B. 2013. The Dynamics of Corporate Co-evolution. Cheltenham: Edward Elgar.

Clegg, S. R. 2017. The East India Company: The first modern multinational? In C. Dörrenbächer \& M. Geppert (Eds), Multinational Corporations and Organization Theory: Post millennium perspectives: 43-67. Bingley: Emerald.

Clegg, S. R., Courpasson, D., \& Phillips, N. 2006. Power and Organizations. Thousand Oaks, CA: Sage.

Darendeli, I. S., \& Hill, T. L. 2016. Uncovering the complex relationships between political risk and MNE firm legitimacy: Insights from Libya. Journal of International Business Studies, 47(1): 68-92.

Dieleman, M., \& Sachs, W. M. 2008. Coevolution of institutions and corporations in emerging economies: How the Salim Group morphed into an institution of Suharto's crony regime. Journal of Management Studies, 45: 1274-1300.

Edwards, T., Sánchez-Mangas, R., Jalette, P., Lavelle, J., \& Minbaeva, D. 2016. Global standardization or national differentiation of HRM practices in multinational companies? A comparison of multinationals in five countries. Journal of International Business Studies, 47(8): 997-1021.

Fellin, T., Foss, N. J., \& Ployhart, R. E. 2015. The microfoundations movement in strategy and organization theory'. Academy of Management Annals, 9: 575-632.

French, J. R. P. Jr., \& Raven, B. 1960. The bases of social power. In D. Cartwright \& A. Zander (Eds), Group Dynamics: Research and Theory: 607-623. New York: Harper and Row.

Geppert, M., Becker-Ritterspach, F., \& Mudambi, R. 2016. Politics and power in multinational companies: Integrating the international business and organization studies perspectives. Organization Studies, 37(9): 1209-1225.
Gifford, B., \& Kestler, A. 2008. Toward a theory of local legitimacy by MNEs in developing nations: Newmont mining and health sustainable development in Peru. Journal of International Management, 14(4): 340-352.

Lukes, S. 2005. Power: A Radical View (2 ${ }^{\text {nd }}$ edn). Basingstoke: Palgrave Macmillan.

Meyer, K. E., Ding, Y., Li, J., \& Zhang, H. 2014. Overcoming distrust: How state-owned enterprises adapt their foreign entries to institutional pressures abroad. Journal of International Business Studies, 45(8): 1005-1028.

Mohr, L. B. 1982. Explaining Organizational Behavior. San Francisco, CA: Jossey-Bass.

Pfeffer, J. 1981. Power in Organizations. Marshfield, MA: Pitman.

Rathert, N. 2016. Strategies of legitimation: MNEs and the adoption of CSR in response to host-country institutions. Journal of International Business Studies, 47(7): 858-879.

Van Hoorn, A., \& Maseland, R. 2016. How institutions matter for international business: Institutional distance effects vs institutional profile effects. Journal of International Business Studies, 47(3): 374-381.

\section{Endinotes}

' I am grateful to Jean Boddewyn and Joanna Karmowska, who offered many incisive comments on a previous draft, and I also appreciate the suggestions made by Carole Couper and Suzana Rodrigues.

${ }^{2}$ To save space, I shall focus on the external politics of MNEs vis-à-vis host-country institutions, especially government agencies and NGOs. This is not to belittle the importance of politics and power within the multinational corporation - a field that is making encouraging progress and which holds out the promise of significant integration between insights from IB and organization theory (Geppert, Becker-Ritterspach, \& Mudambi, 2016).

${ }^{3}$ Put simply, variance analysis examines the variance in a dependent variable accounted for by independent variables while process analysis is concerned with understanding the nature and sequence of conditions that link variables together (Mohr, 1982).

${ }^{4}$ The micro-foundations view highlights how individual-level factors help to account for the ability of firms to formulate and sustain corporate policies and routines (Fellin, Foss, \& Ployhart, 2015).
John Child (i.child@bham.ac.uk) is Professor at Birmingham University, UK. He received his PhD and ScD from the University of Cambridge. He is a Fellow of the British Academy (FBA) and of the AIB. He is widely published. Among his 24 books, Corporate Co-evolution, co-authored with Suzana Rodrigues, won the Academy of Management's 2009 Terry Book Award. His current interests focus on hierarchy and its social consequences, and on the internationalization of SMEs. 